\title{
Mode in Theoretical and Empirical TBLT Research: Advancing Research Agendas
}

\author{
Roger Gilabert \\ Universitat de Barcelona, Spain \\ rogergilabert@ub.edu \\ Rosa MANCHÓN \\ Universidad de Murcia, Spain \\ manchon@um.es \\ Olena VASYlets \\ Universitat de Barcelona, Spain \\ vasylets@ub.edu
}

\section{ABSTRACT}

In this article we explore how oral and written modes may differentially influence processes involved in second language acquisition (SLA) in the context of task-based language teaching (TBLT). We first start by reflecting on the differences between spoken and written language. In what follows, we provide a general description of tasks in relation to the SLA processes. We then establish the links between the learning processes and task phases/features in the two modes. Concluding that the role of mode has been underresearched, we call for a more integrative and modesensitive TBLT research agenda, in which hybridness of discourse (i.e., mingling of the two modes within one communicative event/task) is taken into account.

\section{INTRODUCTION}

The key tenet in task-based language teaching (TBLT) is that a second language (L2) can be best acquired through the performance of real-life communicative tasks (Ellis, 2003; Long, 2015, 1985; Skehan, 1998). Two main reasons have motivated research into tasks. First, communicative task performance may induce learners to pay attention to and retain information from the language they are using, which may bring about changes in their interlanguage systems. The conditions under which learners' learn new forms, and when and how they acquire them have been central questions in TBLT theory and research. Second, and from a more pedagogical perspective, research into tasks can help in the identification of those task features that may impact on language processing for comprehension, production, and learning, hence providing empirical evidence for pedagogic task and materials design. Teachers and syllabus designers may choose certain designs and conditions of performance in order to gear learners' attention toward specific aspects of the language and, in this way, promote opportunities for learning and 
development of their interlanguage system and of their overall communicative competence.

Despite the relevance of task design considerations for teaching and learning, as noted above, scarce empirical attention has been paid to oral and written modes as a task design option (García Mayo \& Azkarai, 2016 e.g., Kormos, 2014; Tavakoli, 2014). In fact, some voices (e.g., Kuiken \& Vedder, 2011) have noted the absence of mode as an integral element in Robinson's theorizing (e.g., Robinson, 2001; Robinson \& Gilabert, 2007) as well as the relevance to redress this situation (e.g., Kormos, 2014. See also Plonsky \& Kim, this volume). It seems likely, however, that due to the idiosyncrasies of speech and writing, oral and written tasks may represent rather distinct language learning environments in terms of second language acquisition (SLA) processes. In the realm of L2 writing, for example, recent theoretical (e.g., Manchón, 2011; Williams, 2012) and empirical (e.g., Manchón \& Roca de Larios, 2011; Ruiz-Funes, 2015) initiatives have explored what is unique about writing that can contribute to interlanguage development. However, there have been very few attempts to understand and contrast the language learning potential of both oral and written modes in task design (but see Kormos, 2014; Manchón, 2014b). Research into such contrasts would be especially relevant since oral and written languages coexist within the same mental space, constituting a synergistic system in which they "constantly feed and modify each other" (Ravid \& Tolchinsky, 2002, p. 430). The blending of spoken and written modes also occurs in real-life language tasks, which frequently require the use of both oral and written language in the achievement of task-related communicative goals. It follows that in order to account for the complexity of real-life performance in its full range, "it makes all theoretical and practical sense to explore the learning opportunities potentially afforded by all language modalities" (Manchón, 2014a, p. 18).

This article is intended as a further contribution to recent attempts to fill this gap (see Byrnes \& Manchón, 2014). Adopting a cognitive perspective in instructed SLA, our aim is to explore how mode may induce and/or influence SLA processes. Mode in this context is understood in both a broad sense (i.e., the aural and written input learners are exposed to as well as the oral and written output they produce) and a narrow sense (i.e., oral and written tasks). Given the scant attention paid to writing in TBLT theory and research, together with recent claims on how writing itself and the processing feedback on one's own writing may be conducive to learning, it becomes relevant, both theoretically and empirically, to explore the manner in which mode can (similarly or differentially) influence L2 learning. This is the main focus of this chapter. In order to fulfil this goal, we will start by reflecting on the differences between spoken and written language. A general description of tasks in relation to cognitive learning processes is then provided, and links between SLA processes and task design phases and features in the two modes are established. The analysis of the impact of mode on SLA processes will lead us to draw implications for TBLT theorizing, task design, and classroom practices. We finish with suggestions regarding the 
manner in which the role of mode can be incorporated in future TBLT research agendas.

\section{DEFINING TASKS AND LANGUAGE MODE}

General definitions of the construct of task are numerous (see Bygate, Skehan, \& Swain, 2001, for a review of definitions), but the common idea is that a task should be a goal-oriented, meaningful activity, involving holistic oral and/or written language use. Additionally, a task must provide a context for the activation of acquisition processes and hence "promote language development through process or product or both" (Samuda \& Bygate, 2008, p. 69). As language comprehension, production, and learning activities, spoken and written tasks share common features, but they are also different. Importantly, as we elaborate in more detail in later sections, these differences are crucial when discussing the language learning potential that may derive from oral and writing tasks.

Relevant comparisons between speech and writing can be made by considering the physical characteristics of the act of production (e.g., speed), characteristics of the output (e.g., editability), and also the writers' or speakers' relationship with the audience (Horowitz \& Samuels, 1987; Olson, Torrance, \& Hildyard, 1985). Generally, speech can be defined as phonic language, characterized by a high (as compared to writing) speed of delivery and the evanescence of the resulting output. Oral language is typically produced and processed in the context of the physical presence of the listener(s), who can often respond with their own language. Rapidity and nonpermanence of speech may constrain input, intake, or feedback processing in oral tasks, and they may also limit the processes of online planning, linguistic encoding, and monitoring or editing during oral performance. Because of the immediate presence of the audience, the language generated in oral tasks performs its communicative function at the moment of its creation, and a part of the meaning can be transferred through nonverbal channels (e.g., gestures). Furthermore, if an oral task is interactive or collaborative, speakers can source each other with grammar and lexis, or they provide immediate feedback, which can trigger a range of useful processes such as noticing or discourse monitoring.

Writing is graphic language, which, as opposed to speech, is slow and selfpaced in production, but visible and permanent in output. A writer's audience is typically displaced in place and in time. The slow pace and visibility convert a writing task into a self-regulated and recursive process, which affords learners time and possibilities to attend to input and also facilitates intake or feedback processing. When producing written output, learners can strategically distribute their cognitive resources as well as extensively plan (including during production), carefully encode, and monitor or edit their language (Manchón \& Williams, in press). There is also more possibility to deploy explicit knowledge or consult external sources (e.g., dictionaries). Absence of immediate audience eliminates the pressure of a fast response but, at the same time, converts an individual writing task into a solitary and self-contained activity, which may add to its difficulty. In 
previous discussions of the effectiveness of speaking and writing tasks, Williams (2012), for example, singled out pace and permanence of writing as the main features to facilitate learning. In Williams's view, these characteristics may allow more learner control over attentional resources, as well as a greater need and a better opportunity for focus on form and use of explicit knowledge both during and after task performance. In a similar line, Polio (2012) assumed that even under time pressure, any writing task "can tap into both explicit and implicit knowledge, in contrast to speaking tasks, which more often require implicit knowledge to complete fluently" (p. 322).

Our previous description may present oral and writing tasks as a sort of a dichotomy, which, however, does not correspond in full to what happens during L2 task performance. What really happens is that in tasks, modes may vary within and among task types (e.g., individual writing versus collaborative writing tasks, with the latter potentially including much more interaction of speaking and writing activities) and across task phases (e.g., written input provided during the pretask may be recycled and incorporated during oral task performance). Mingling of modes also happens in computer-mediated communication (CMC), which reshapes the characteristics and the learning potential of oral and writing tasks. For example, synchronous text-based communication is a unique combination of speech and writing, as it represents interactive discourse unfolding in real time, as in an oral dialogue, but also leaves a visible record, as in writing (Smith, 2003). The full discussion of the singularity of technology-mediated tasks is beyond the scope of this article. However, the learning potential of tasks in the context of CMC seems to be promising and deserves thorough exploration in future research (see also González-Lloret \& Ortega, 2014; Sauro, 2011; Thomas \& Reinders, 2010).

Going back to the characterization of tasks within the dimension of mode, we would like to conceptualize tasks as existing in a multidimensional oral or written space in the form of numerous, often overlapping variations. Each of these variations would represent an adaptation of language to the particular conditions of use. These variations may possess prototypical oral or written task features, or they may range (as one of the reviewers of this article has suggested) from low-to-high writing involvement in oral-based tasks to low-to-high oral involvement in written-based tasks. The orality-literacy model by Koch and Oesterreicher (1994) appears to be convenient to illustrate this thesis (Figure 1). This model distinguishes between the dichotomic medial dimension (language can be either phonic or graphic) and conceptual dimension. The two poles of the conceptual dimension are "language of immediacy" (unplanned discourse in a dialogic setting) and "language of distance" (planned formal discourse for remote audience).

As in Dürscheid and Frehner (2013), we would like to use this model to show the location of different types of tasks within the mode dimension. Thus, prototypical writing tasks (e.g., written essays) could be placed at the pole of the graphic language of distance (Position 1), while prototypical oral tasks (e.g., oral dialogues) would be at the extreme of the phonic language of immediacy (Position 2). Position 3 would correspond to a hybrid-type task, like a text-based chat, which is written from the point of view of the medium, but which is more oral conceptually, as 


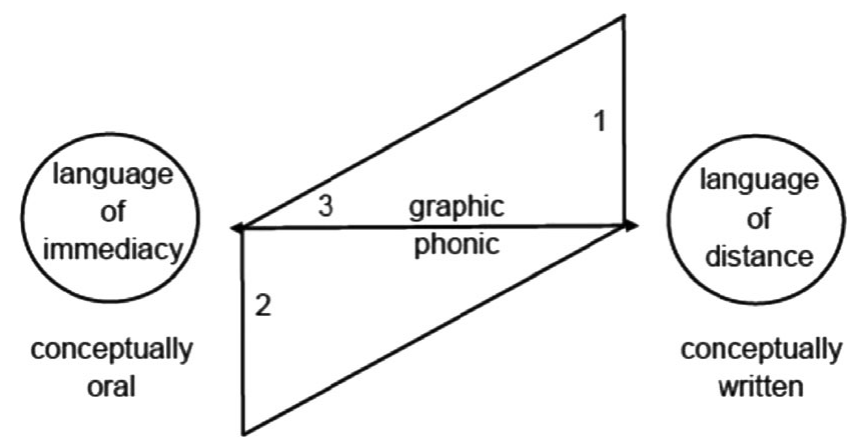

FIGURE 1. Koch and Oesterreicher's (1994) orality-literacy model

(Notes: 1 = individual writing task; 2 = interactive oral task; $3=$ interactive text-based CMC task)

it displays many features of spoken dialogue such as interactivity or provision of immediate feedback.

The design of holistic communicative tasks may also combine the two modes in input-output cycles (Basterrechea, García Mayo \& Leeser, 2014), in which speech and writing blend and alternate. In pedagogic practice, listening tasks during pretask work may typically have a written outcome or may turn into oral discussion. Similarly, the outcome of interactive tasks may be a public oral presentation, whose preparation may entail some written work on the part of learners. TBLT research has often kept the two modes separately for good reasons, but a more hybrid and dynamic approach may be needed. We will return to the issue of mode "hybridness" at the end of this article. For the time being, let us simply add that the issue of hybridness also has important pedagogical implications, as pedagogic tasks should help L2 learners in the performance of real-world tasks, many of which, as just noted, entail combination and interaction of modes.

We now turn our attention to the consideration of how mode interacts with learning process during task execution.

\section{TASKS AND LEARNING PROCESSES}

Whether inside or outside the confines of the classroom, when L2 learners engage in task performance, they are typically exposed to input and produce output (both external to the learner), and as a consequence, learners engage in both input and output processing, by which they activate some, many, or all micro- and macroprocesses (Doughty, 2001) involved in language learning.

In what follows we resort to Leow's (2015) model of SLA in order to give structure to our analysis of processes in relation to modes in tasks, since his comprehensive model brings together the commonly agreed-upon constructs and phases of L2 development (see Figure 2). Beyond excellent previous attempts at relating task-based learning to some important SLA processes (Robinson, 2011), 


\begin{tabular}{|c|c|c|c|c|c|c|}
\hline INPUT & $\{>$ & INTAKE & $>$ & INTERNAL SYSTEM & $>\}$ & OUTPUT \\
\hline & Stage 1 & Stage 2 & Stage 3 & Stage 4 & Stage 5 & \\
\hline (Product) & (process) & (Product) & (process) & (product) & (process) & (product) \\
\hline (input) & (input) & (intake) & (intake) & (L2 knowledge) & (L2 knowledge/ou & $\begin{array}{l}\text { (representative } \\
L_{2} \text { knowledge) }\end{array}$ \\
\hline
\end{tabular}

FIGURE 2. Stages of the learning process in SLA: of processes and products

Leow's model can, to the best of our knowledge, provide theoretical support to all the processes and products that can be generated by tasks.

In Leow's (2015) model, input and output are external products, while learning is conceptualized as encompassing both products and processes. Learning as a process is internal and comprises the stages of (1) input processing (the initial stage of the learning process, which contains the phases of perception, detection, and noticing of both content and linguistic data found in the input), (2) intake processing (form-meaning connections, hypothesis formation, and testing, as well as hypothesis modification, rejection or confirmation), and (3) L2 knowledge processing (integration and analysis of L2 internal representations, and also learning resulting from the learners' manipulation of L2 knowledge). Learning as a product is presented both internally (L2 knowledge) and externally (representative L2 knowledge). As mentioned above, tasks are generators of input and output and are susceptible of potentially generating all the internal processes and products included in Leow's model, to which now we turn.

\subsection{Input and Input Processing in Tasks}

There is a general consensus that input is necessary for learning (Gass, 1997), hence the attention paid to input in SLA research. Second language learners are exposed to the aural and written input outside the classroom, which can be made available to them by chance (Sharwood-Smith, 1993). In the classroom, and this time by design, the amount, quality, and access to input can vary considerably depending on teaching approaches and practices (Long, 2015; Long \& Robinson, 1998). In the context of TBLT, input often takes the shape of positive evidence of the target language or is presented as corrective feedback, and it is typically part of a dynamic, goal-oriented, input-output-feedback cycle in both the oral and written modes.

Input, however, is external to the learner, and what forms get noticed and further processed will depend on both its characteristics (e.g., saliency, communicative value of the forms) and what the learner brings to the task (i.e., her or his own internal syllabus, the learners' communicative needs, developmental readiness, felt task demands, prior language knowledge in terms of L2 proficiency or first language [L1], processing capabilities, motivation, task construal, and agency, 
among many other factors or combinations of factors) (for a review, see Han, Park, \& Combs, 2008).

Following Leow (2015), new forms in the input may go through different degrees of attention and memory processing. By far, most of the research into input processing has investigated the construct of noticing (Robinson, 1995, 2003; Schmidt, 2001). Noticing has been researched in relation to positive evidence largely through visual input enhancement in the written mode (see Lee \& Huang, 2008, for a meta-analysis) far more that it has in the aural mode (Cho \& Reinders, 2013). Input flooding (Arteaga, Gess, \& Herschensohn, 2003; White, 1998) has also been mainly exploited in the written mode, as has task-essential language. The written mode, to a higher extent than the aural mode, has also been manipulated through input simplification (Leow, 1995), input elaboration (Oh, 2011), and explicit teaching (Carroll \& Swain, 1993; Leow, 2000), mainly not from a TBLT perspective. Research into noticing in TBLT-oriented research agendas has been more extensive in relation to task demands; see the tenets of the cognition hypothesis and its claims about better and longer retention of noticed input (Robinson, 2007, 2011; Robinson \& Gilabert, 2007), output (Izumi, Bigelow, Fujiwara, \& Fearnow, 1999), teacher-learner interaction and corrective feedback especially through recasts (see Mackey \& Goo, 2007, for a meta-analysis), and learner-learner interaction (e.g., Philp \& Iwashita, 2013; Robinson, 2007). Despite its potential relevance, the study of written corrective feedback as a form of interaction and input provision has been surprisingly absent in TBLT research agendas which have previously focused mainly on oral tasks (Manchón, 2014b; but see work by Sachs \& Polio, 2007, who, without directly mentioning TBLT, explored the effectiveness of reformulations versus error corrections in a writing task).

When contrasting the two modes and the level of input processing, aural input modification can be both preplanned and spontaneous during conversations in class. In oral tasks, input enhancement may be applied by means of stress, intonation, and gestures (Gascoigne, 2006). Input flooding may be used to build repetition, redundancy, and input elaboration by means of paraphrase and provision of synonyms, and task-essential language can be built into the transcripts of listening comprehension tasks. The same techniques can be employed during the implementation of task-based lessons through teacher talk, which can be consciously manipulated in order to increase the likelihood that certain forms may be attended to (e.g., Moser, Harris, \& Carle, 2011). Because of working memory (WM) limitations, aural input poses considerable attentional demands as new forms stay available for noticing for just a fraction of a second. The challenge is even greater for further processing following noticing (e.g., form-function mapping or hypothesis formation). On the contrary, the permanence and self-paced nature of processing written input supplied to learners may liberate attentional resources that may facilitate noticing (and that is why, for example, most vocabulary is learned through reading). In writing, input provision (and corresponding modifications) can take many forms, including reading materials in reading-to-write tasks or listening material (e.g., dictogloss tasks). In addition, as noted above, feedback in 
writing is an important source of input, which can also take many forms, including both oral input in the provision of feedback in conferencing at some point during the task cycle (not necessarily limited to the posttask phase), or written input in the form of more and less direct and indirect forms of written corrective feedback (including error correction, modeling, or reformulation). No systematic agenda is available, however, for researching input transformations in TBLT, as opposed to the more systematic TBLT agenda associated with output or interaction (see section 3.4).

Feedback studies in the oral domain, for example, have shown us that under certain circumstances, oral feedback may not be noticed and therefore is not processed any further $(\mathrm{Goo}, 2012)$, and so there have been theoretical claims for an advantage for noticing feedback in CMC tasks (although, for contesting evidence, see Gurzynski-Weiss \& Baralt, 2014). In contrast to the oral feedback, which has to be attended online, corrective written feedback is usually explicit and visible, and there is more time to process it. Although these factors do not guarantee learning, they undoubtedly facilitate feedback noticing, which is a prerequisite for uptake and further processing. A number of recent studies, which employed immediate and delayed posttests as a measure of learning, demonstrated that written, corrective feedback improved accuracy of performance and retained it over time (Bitchener $\&$ Knoch, 2008, 2010; Sheen, 2007). However, in spite of the positive evidence for the role of written feedback in SLA, it is not yet clear how extensive this role might be, or which types of learners (e.g., in terms of L2 proficiency or cognitive abilities) can benefit from it most (Bitchener, 2012).

In terms of methods used to tap into learning processes, it is probably easier to measure processes such as "noticing" by means of online methods in the written mode. Eye tracking has been used to measure noticing in written input (Godfroid, Boers, \& Housen 2013; Godfroid \& Uggen, 2012), and so have think-aloud protocols and marking (Park, 2011) in written tasks. In oral tasks, the offline measures such as the measurement of uptake (Bao, Takako, \& Han, 2011), retrospective protocols or stimulated recall can be used after oral task performance (see section 3 in Leow, 2015, for a review of methods to measure noticing; Philp \& Iwashita, 2013).

The outcome of noticing, which we now turn to, is also referred to as intake.

\subsection{Intake and Intake Processing}

Reinders (2012, p. 28) defined intake as "a subset of the detected input (comprehended or not), held in short-term memory, from which connections with longterm memory are potentially created or strengthened." As we saw in the previous section, although enhanced saliency of input is likely to promote noticing, noticing by itself does not guarantee acquisition. Noticed features in the input need to be processed further and converted into intake. According to VanPatten (2011), the process of the conversion of input into intake involves establishing form-meaning 
connections, which can be defined as the process of associating these two aspects of language and which are constructed on the basis of input and output. This process is conceptualized as incremental and recursive. Establishing form-meaning connections does not imply automatic acquisition, but its product (i.e., intake), which is stored in working memory, holds the potential of being further processed and incorporated into the L2 system. Establishing form-meaning connections can be mediated by different factors such as the nature of the input, learner characteristics, and the learning context and instruction (VanPatten, Williams, \& Rott, 2004).

As for research into intake processing from a TBLT perspective, TBLT is in need of a systematic agenda looking at the effects of tasks on intake (see Reinders, 2005, for an exception). The bulk of TBLT studies have focused on output and interaction to a much larger extent than internal processes such as noticing or the conversion of input into intake. As Reinders (2005, p. 150) has suggested, one of the issues with intake is its measurement and the difficulties in operationalizing it. Typically, intake tests need to be administered soon after exposure to the L2, with tests such as forced recognition being probably the most appropriate for capturing intake. Other types of tests involving output (e.g., fill-in-the-blanks) may reflect acquisition rather than intake (see Reinders, 2005, for a discussion on the issue). Verbal protocols during task performance (e.g., in collaborative tasks) have also been claimed to aid the measurement of intake. In addition to intake, learners may engage in hypothesis formation and testing (Chaudron, 1985), which have also been referred to as mental (Sharwood-Smith, 1986) or cognitive comparisons (Doughty, 2001), although such comparisons are not open to introspection.

As far as mode is concerned, input in both modes has the potential to engage learners with the transformation of noticed input into intake through form-meaning connections. Aural input is evanescent in nature, while the fixed nature of written input may encourage learners to move beyond the simple registration of new items and hence engage in intake processing. We would like to speculate that access to written input during task performance may facilitate intake processing mechanisms because the written mode allows for WM processes to be activated following noticing (Robinson, 2011). The potential step-by-step nature of the written mode may promote recursiveness, that is the learners' going back to unknown, new items in the input, and can also facilitate available resources for engaging in hypothesis formation and cognitive comparisons. The provision of corrective feedback during L2 interaction, typically in the context of tasks, has been claimed to create the conditions that facilitate form-meaning connections. One of the claims of the cognition hypothesis (Robinson, 2011) is that, in terms of the learning effects, enhanced cognitive task demands are expected to direct learners' attention to the similarities and differences of the conceptual systems in L1 and L2, as well as to the ways these concepts are expressed linguistically. As a consequence of engaging in task work, either in interaction with feedback or in complex tasks performance, or both (e.g., Kim, 2012; Révész, 2009), the development of new form-function mappings is expected to take place. While we have clear definitions of noticing and specific ways to measure it, explanations as to how exactly form-meaning connections work, how hypotheses about the language are formed, how cognitive 
comparisons are established, and how all of them may be measured still remain elusive. Both outside and inside of the TBLT field, the definition of intake and its measurement will need more attention from research.

\subsection{L2 Knowledge and Knowledge Processing}

Knowledge processing includes internalization, modification, and consolidation of knowledge (Leow, 2015). With a few notable exceptions (e.g., Cadierno \& Robinson, 2009), this is an area where TBLT research has probably advanced the least. Associated with knowledge processing are reconceptualization or restructuring leading to grammatization and syntactization in the L2 (Robinson, 2011). Automatization and consolidation of memories are also considered dimensions of knowledge processing.

From the perspective of the idiosyncrasies of oral and written modes, it would seem reasonable to suggest that such processes, which require deeper level of processing, would be facilitated in the written rather than in the oral mode. However, up until now there is no compelling evidence that shows any advantages of any of the modes over the other, and, certainly, TBLT research would benefit from studies in the area of knowledge processing. An explanation for this lack of studies could be that knowledge processing is not open to direct inspection (see, however, the enormous advances in our understanding and measurement of implicit and explicit knowledge in Rebuschat, 2015).

\subsection{The Language Learning Potential of Oral and Written Output Practices}

As Leow (2015) put it, output is both a product (what is learned) and a learning process within the knowledge processing stage. The TBLT research agenda has mainly focused on output as a product (i.e., task performance studies). Since the mid-1990s, considerable research efforts have been put into measuring the effects of manipulating task design features on both L2 performance (typically operationalized as complexity, accuracy, and fluency, or CAF; see, e.g., Robinson, 2011; Skehan, 2009) and L2 acquisition. We refer readers who are interested in the similarities and differences between the thoroughly compared cognition hypothesis and the limited capacity model, and their associated prolific empirical findings on performance, to the work by Bygate (2015) and the meta-analysis by Sasayama, Malicka, and Norris (forthcoming). For reasons of space and because we are interested in learning processes, here we focus instead on output as part of the learning process in relation to mode in TBLT.

From an acquisitional perspective, the output hypothesis (Swain, 1995, 2005) has posited that "the act of producing language (speaking or writing) constitutes, under certain circumstances, part of the process of second language learning" (Swain, 2005, p. 471), moving learners from semantic processing in comprehension to more syntactic processing in production. Syntactic processing demands higher attention to linguistic forms and deeper language analysis, with potential consequent effects on language development. The production of output is 


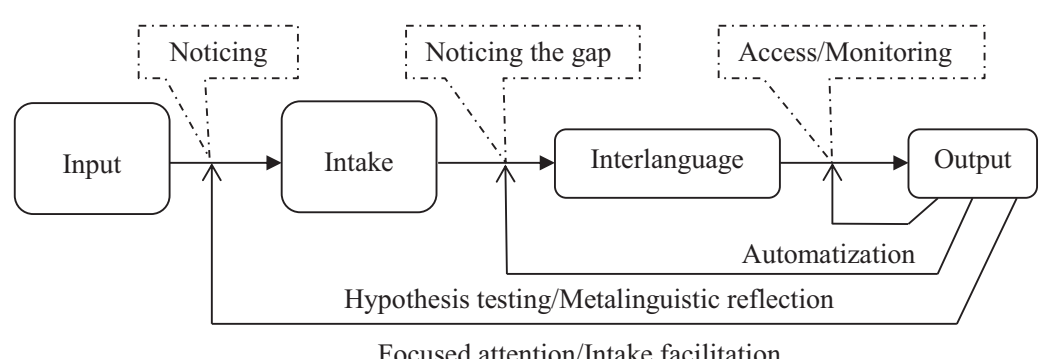

FIGURE 3. Effects of output on SLA processes (from Izumi, 2003, p. 188).

postulated to trigger the whole range of beneficial processes, such as noticing and focus on form, hypothesis testing, metalinguistic reflection, and automatization (DeBot, 1996; Erlam, Loewen, \& Philp, 2009; Uggen, 2012; Swain, 1995, 2005) (see Figure 3). What the TBLT paradigm precisely offers is the optimal context for the sustained and context-embedded type of output practices that theorists consider vital for L2 development.

The crucial point here is that the learning possibilities stemming from output practices may work differently in oral and written tasks. The noticing function during output production refers to both holes and gaps - in other words, becoming aware of the holes in interlanguage and also "noticing the gap between the interlanguage and the target language" (Muranoi, 2007, p. 57). Such detection is expected to engage learners in the analysis of their existing interlanguage and may promote a more form-focused, syntactic analysis of the incoming input, this input including the whole range of options mentioned in an earlier section. Noticing of linguistic problems can occur in both oral and written tasks, although it is in principle more likely to take place in writing. Because of the evanescent nature of oral output, learners may register linguistic inconsistencies only transiently, with the result that even if noticed, the noticed elements can fade away from the speaker's WM without any further processing. In contrast, the permanence and self-paced nature of writing may provide more of a facilitative context for both noticing and further processing. As Doughty (2001) put it, the ability to notice the gap and perform cognitive comparisons demand "sufficient and coordinated working and long-term memory resources" (p. 225). As the visibility of the written output provides certain relieving effects for working memory, we could suggest that cognitive comparison is also facilitated during the performance of the written task. As for the TBLT research agenda, we agree with Philp and Iwashita (2013), who suggested that there is a paucity of studies directly looking at noticing in interaction, and we make it extensive to studies dealing with monologic oral tasks (see, however, Gilabert, 2007). Noticing in written tasks has been directly addressed in several studies (Izumi \& Bigelow, 2000; see also Michel \& Smith, forthcoming, on priming and noticing measured with eye tracking).

Output can also serve as a way for learners to try out new linguistic structures (i.e., hypothesis testing). Learners can test their hypotheses against external 
feedback or by relying on their own internal devices. The permanent record of written output also facilitates this crucial learning process, as writers can conveniently review and contrast their L2 hypotheses against future input (Schoonen, Snellings, Stevenson, \& van Gelderen, 2009). Relief for working memory resources through the visible text and availability of time can also facilitate hypothesis testing during writing tasks, as learners can devote more time and more cognitive resources to this mental operation. As Williams (2012) expressed it, "the cognitive window is open somewhat wider and learners have a richer opportunity to test their hypotheses when they write than when they speak" (p. 328). Hypothesis testing has been operationalized as associated with language-related episodes in face-to-face oral interaction (Mackey, 2007; Swain, 1998) where there exists a prolific literature, and it is being also extended to written and oral CMC (Hamano-Bunce, 2010). It is still an empirical question whether or not these learning opportunities also apply to technology-mediated tasks (see González-Lloret \& Ortega, 2014).

Another learning function of output is the metalinguistic one. The claim is that "as learners reflect upon their own target language use, their output serves a metalinguistic function, enabling them to control and internalize linguistic knowledge" (Swain, 1995, p. 126). In line with the theory of mind, Swain posited that the use of language produced by other parties or by the learners themselves, mediates L2 learning. The idea is that learners externalize their thinking and thus have an object to reflect upon that helps them to crystallize their ideas and detect problematic issues in their interlanguage. Writing tasks again appear to function differently as far as metatalk is concerned. In an individual writing task, learners cannot benefit from the metatalk of an external party, and therefore metalinguistic dialogue is restricted to dialoguing with oneself. This restriction, however, does not exist in collaborative classroom writing or in text-based CMC tasks, where learners are provided with a conversational partner. In any type of writing, the writer's thoughts are externalized into a visible text, which supplies the primary basis for the metalinguistic discussion.

Another function of output proposed by DeBot (1996) is that of developing automaticity. Drawing on Levelt's (1989) model of speech production, DeBot argued that output practice enhances fluency and thus contributes to converting declarative knowledge into procedural with a consequent increased control over and consolidation of learners' interlanguage (also suggested in more recent work on the impact of practice on learning — see DeKeyser, 2007). In his theorizing, DeBot seemed to take the oral mode as the default mode in which the function of automaticity is deployed. It is a matter for future research to compare the way automaticity is fostered by oral versus writing modes in tasks. In the TBLT agenda, automatization as the consequence of engaging in task performance has been explored from Robinson's (2007, 2011) cognition hypothesis. Robinson (2011) claimed that increasing the cognitive complexity of tasks along resource-dispersing dimensions (e.g., by reducing planning time) fosters automatization and helps learners progressively engage in tasks that gradually approximate real task performance. Also, as part of the cognition hypothesis, the SSARC (stabilize, simplify, automatize, restructure, complexify) model (Robinson, 2010) for task sequencing claims that performing 
simple-to-complex sequences of tasks may foster automaticity and more efficient scheduling of the components of complex L2 task performance.

\section{MODE IN TBLT RESEARCH: CONCLUSION AND FUTURE}

RESEARCH

A series of conclusions can be drawn from our analysis of mode in relation to learning processes in TBLT. First, mode as an option in task design has been underresearched. Globally considered, the oral mode has received more attention than the written mode (e.g., in interaction studies) in TBLT theory and research, and it is only recently that the contrast between the two modes has been approached in an emerging line of research on task-modality effects (for a review, see Kuiken \& Vedder, 2012; see also García Mayo \& Azkarai, 2016; Kormos, 2014; Kuiken \& Vedder, 2011; Tavakoli, 2014; Weissberg, 2000). Despite these developments, the tendency to separate modes and treat them individually still prevails in TBLT scholarship. This is in sharp contrast with what we know about tasks and task performance both inside and outside classrooms. Outside the classroom, needs analysis and the analysis of target tasks show that modes are intertwined in complex ways in task-based discourse (Long, 2015). Inside the classroom, written texts become alive as they generate inspection and discussion in pair or group work, and comprehension and production may happen in an interplay of modes. At this point, therefore, such hybridness of modes in tasks may not be fully represented in task-based research. With the exception of task-based studies looking at inputoutput cycles where learners process written input to then engage in oral interaction in the creation of oral and written products (e.g., de la Fuente, 2002; Ellis \& He, 1999; Izumi, 2002; Izumi et al., 1999; Niu, 2009), little research has focused on how modes interact with and feed on one another during task execution and performance. Therefore, little is known about how and why the interaction of modes may contribute to language learning in tasks. We would like to speculate that acquisition may proceed in the mingling and interweaving of modes, where, for example, new forms in written or aural input foster acquisitional processes, which are later supported by input-output-feedback cycles, which in turn result in written or oral products.

In this sense, hybridness can also be inspected from the point of view of the different phases of tasks and the interaction among them. Overwhelmingly, and as we have seen in our analysis of research into learning processes in relation to mode, research has focused on the task phase in task cycles. At least two metaanalyses (Jackson \& Suethanapornkul, 2013; Sasayama et al., forthcoming) show that research on tasks has made a priority of the task execution phase, thus disregarding pretask or posttask work, a limitation that may well derive from the almost exclusive focus of TBLT research on oral tasks. However, as soon as writing tasks are added to the mix, the need to look at pre- and posttask phases becomes much more relevant. Nevertheless, and regardless of whether the focus is on oral or written tasks, how much do we know about how learners work on the input in the pretask phase during task performance or posttask work? How much do 
they engage with the prompts (so crucial in writing) that constitute the input to the task phase? In pedagogic practice, tasks rarely take place without pretasks, and such cycles typically combine exposure to input followed by interaction and meaningful output practice. In some task-based methodological approaches (e.g., Edwards \& Willis, 2005; Willis, 1996), language awareness posttasks are used to consolidate the language attended to during pretask and task work. Writing is usually followed by feedback provision, feedback processing, and further revision and rewriting. Hence, stopping halfway through in our research endeavors seems to be ill founded and certainly a potential limitation to shedding light on the language learning potential of work done in each phase of the task cycle. Accordingly, future research would benefit from examining the language learning potential of tasks as a much more dynamic process, where written texts become verbal and oral practices take finally a written form. Oral and written modes coexist in task performance since oral and written production share the same mental space. We advocate the generation of research that looks at such dynamic aspects of tasks and that does so considering all stages of the task cycle.

Second, regarding available TBLT research on acquisitional processes, most studies have looked either at the processes associated with output practice (e.g., noticing, hypothesis testing, and metalinguistic awareness) or interaction (especially through the provision of feedback during face-to-face interactional exchanges), with much less emphasis on the internal processes of input, intake, and knowledge expansion and consolidation, which are conductive to SLA. If TBLT is going to continue making claims about the benefits of engaging in taskbased performance, in addition to research on output and interaction, additional empirical efforts should go into the study of input processing, intake processing, and L2 knowledge or output processing. This will certainly require sophisticated methodologies and here eye movements recording could assist TBLT scholars in exploring L2 learners' processes (for an evaluation of research methods capturing output processes as a consequence of increasing cognitive load in oral tasks, see Michel, Gilabert, \& Révész, forthcoming; Révész, Michel, \& Gilabert, 2015). This is in fact an avenue explored in our current program of research on task-modality effects (see reference in the Acknowledgments section). In any case, this methodological innovation is not free of problems when it comes to using eye tracking for the analysis of writing processes in the written modality. In short, as noted by Godfroid and Michel (2015), guidelines for the use of eye tracking in TBLT research still need to be established, which includes the guidelines to explore the task-modality effects.

As far as output is concerned, again mode-related variables that may influence the language learning potential of output ought to be further researched. Studies on task-modality effects must necessarily put to the empirical test current predictions on the way in which the idiosyncrasies of output production in speech and writing may facilitate learning processes. Essential items in these research agendas would be to ascertain whether or not the purported learning effects associated with the availability of time and the permanence and visibility of the written text do actually happen, when, how, and for whom. Although, as already mentioned, research 
interests in output and interaction have been central in TBLT research agendas, further inquiries into mode-related differences in these domains are needed. At a minimum, the distinct nature of interaction across modes needs to be acknowledged and the potential consequences theorized and researched. Another related issue that deserves further research is how learning processes may work differently in task performance in which learners move from oral production and interaction to writing, or from writing to an oral product. Such speaking-to-write and writing-tospeak interactions will need attention in the TBLT research agenda. Finally, some recent studies in the field have started to use both online and offline measures to tap into less explored learning processes in either a single mode or the two modes (e.g., see Michel \& Smith, forthcoming, for priming and noticing in CMC as measured by eye tracking; see Gurzynski-Weiss \& Baralt, 2014, for interactional feedback in face-to-face as compared to written CMC).

In sum, we advocate a TBLT-oriented research agenda that is integrative and sensitive to the hybrid nature of discourse and accounts for the interactive and dynamic nature of the learning processes involved in task-based performance. Similarly, and from the perspective of modes, we believe that TBLT research will need to explore performance across phases as interconnected rather than as static and modular.

\section{Acknowledgments}

Our program of research referred to in the article is a long-term, SLA-oriented, L2 writing project. We graciously acknowledge funding by the Spanish Ministry of Economy and Competiveness (Research Grant FFI2012-35839) and the Seneca Foundation, Murcia Regional Government Agency for Science and Technology (Research Grant 19463/PI/14). We would also to thank the GRAL (Language acquisition research group_-2014SGR1089), based at the University of Barcelona, for their support.

\section{REFERENCES}

Arteaga, D., Gess, R., \& Herschensohn, J. (2003). Focusing on phonology to teach morphological form in French. Modern Language Journal, 87(1), 58-70.

Bao, M., Takako, E., \& Han, Y. (2011). Classroom study on noticing and recast features: Capturing learner noticing with uptake and stimulated recall. System, 39, 215-228.

Basterrechea, M., García Mayo, M. P. \& Leeser, M. J. (2014). Pushed output and noticing in a dictogloss: Task implementation in the CLIL classroom. Porta Linguarum 22, 7-22.

Bitchener, J. (2012). A reflection on "the language learning potential" of written CF. Journal of Second Language Writing, 21, 348-363.

Bitchener, J., \& Knoch, U. (2008). The value of written corrective feedback for migrant and international students. Language Teaching Research, 12, 409-443.

Bitchener, J., \& Knoch, U. (2010). The contribution of written corrective feedback to language development: A ten-month investigation. Applied Linguistics, 31, 193-214.

Bygate, M. (2015). Sources, developments and directions of task-based language teaching. The Language Learning Journal. Advanced online publication. Retrieved from http://www.tandfonline.com/doi/full/10.1080/09571736.2015.1039566

Bygate, M., Skehan, P., \& Swain, M. (2001). Researching pedagogic tasks, second language learning, teaching and testing. London, UK: Longman. 
Byrnes, H., Manchón, R. M. (2014). Task-based language learning: Insights from and for L2 writing: An introduction. In H. Byrnes \& R. M. Manchón (Eds.), Task-based language learning-Insights from and for L2 writing (pp. 1-27). Amsterdam, The Netherlands: John Benjamins.

Cadierno, T., \& Robinson, P. (2009). Language typology, task complexity and the development of L2 lexicalization patterns for describing motion events. Annual Review of Cognitive Linguistics, 6 , 245-277.

Carroll, S., \& Swain, M. (1993). Explicit and implicit negative feedback: An empirical study of the learning of linguistic generalizations. Studies in Second Language Acquisition, 15, 357-386.

Chaudron, C. (1985). Intake: On methods and models for discovering learners' processing of input. Studies in Second Language Acquisition, 7, 1-14.

Cho, M., \& Reinders, R. (2013). The effects of aural input enhancement on L2 acquisition. In J. M. Bergsleithner, S. N. Frota, \& J. K. Yoshioka, (Eds.), Noticing and second language acquisition: Studies in honor of Richard Schmidt (pp. 133-148). Honolulu: University of Hawaii, National Foreign Language Resource Center.

Doughty, C. (2001). Cognitive underpinnings of focus on form. In P. Robinson (Ed.), Cognitive and second language instruction (pp. 206-257). Cambridge, UK: Cambridge University Press.

DeBot, K. (1996). The psycholinguistics of the output hypothesis. Language Learning, 46, 529-555.

de la Fuente, M. J. (2002). Negotiation and oral acquisition of L2 vocabulary: The roles of input and output in the receptive and productive acquisition of words. Studies in Second Language Acquisition, 24, 81-112.

DeKeyser, R. (2007). Situating the concept of practice. In R. DeKeyser (Ed.), Practice in a second language (pp. 1-18). Cambridge, UK: Cambridge University Press.

Dürscheid, C., \& Frehner, C. (2013). Email communication. In S. Herring, D. Stein \& T. Virtanen (Eds.), Pragmatics of computer-mediated communication: Vol. 9 (pp. 35-54). Boston, MA: Walter de Gruyter.

Edwards, C., \& Willis, J. (2005). Teachers exploring tasks in English language teaching. London, UK: McMillan.

Ellis, R. (2003). Task-based language learning and teaching. Oxford, UK: Oxford University Press.

Ellis, R., \& He, X. (1999). The roles of modified input and output in the incidental acquisition of word meanings. Studies in Second Language Acquisition, 21, 285-301.

Erlam, R., Loewen, S., \& Philp, J. (2009). The roles of output-based and input-based instruction in the acquisition of L2 implicit and explicit knowledge. In R. Ellis, S. Loewen, C. Elder, R. Erlam, J. Philp, \& H. Reinders (Eds.), Implicit and explicit knowledge in second language learning, testing and teaching (pp. 241-261). Clevedon, UK: Multilingual Matters.

García Mayo, M. P. \& Azkarai, A. (2016). EFL task-based interaction: Does task modality impact on language-related episodes? In M. Sato \& S. Ballinger (eds.) Peer Interaction and Second Language Learning Pedagogical potential and research agenda (pp. 241-266). Amsterdam: John Benjamins.

Gascoigne, G. (2006). Toward an understanding of incidental input enhancement in computerized L2 environments. CALICO Journal, 24, 147-162.

Gass, S. M. (1997). Input, interaction, and the second language learner. Mahwah, NJ: Erlbaum.

Gilabert, R. (2007). Effects of manipulating task complexity on self-repairs during L2 oral production. International Review of Applied Linguistics in Language Teaching, 45(3), 215-240.

Godfroid, A., Boers, F., \& Housen, A. (2013). An eye for words: Gauging the role of attention in incidental L2 vocabulary acquisition by means of eye tracking. Studies in Second Language Acquisition, 35(3), 483-517.

Godfroid, A., \& Michel, M. (2015). Eye-movements during task-based performance: What can we learn? Colloquium at the 6th International Conference of TBLT, September 16-18, Leuven, Belgium.

Godfroid, A., \& Uggen, M. (2012). Attention to irregular verbs by beginning learners of German: An eye-movement study. Studies in Second Language Acquisition, 35, 291-322.

González-Lloret, M., \& Ortega, L. (2014). Technology-mediated TBLT: Researching technology and tasks. Amsterdam, The Netherlands: John Benjamins.

Goo, J. (2012). Corrective feedback and working memory capacity in interaction-driven L2 learning. Studies in Second Language Acquisition, 34, 445-474.

Gurzynski-Weiss, L., \& Baralt, M. (2014). Exploring learner perception and use of task-based interactional feedback in FTF and CMC modes. Studies in Second Language Acquisition, 36, 1-37.

Hamano-Bunce, D. (2010). Talk or chat? Chatroom and spoken interaction in a language classroom. ELT Journal, 65(4), 426-436.

Han, Z. H., Park, E., \& Combs, C. (2008). Textual input enhancement: Issues and possibilities. Applied Linguistics, 29(4), 597-618. 
Horowitz, R., \& Samuels, S. (1987). Comprehending oral and written language. New York, NY: Academic Press.

Izumi, S. (2002). Output, input enhancement, and the noticing hypothesis. Studies in Second Language Acquisition, 24, 541-577.

Izumi, S. (2003). Comprehension and production processes in second language learning: In search of the psycholinguistic rationale of the output hypothesis. Applied Linguistics, 24, 168-196.

Izumi, S., \& Bigelow, M. (2000). Does output promote noticing and second language acquisition? TESOL Quarterly, 34(2), 239-278.

Izumi, S., Bigelow, M., Fujiwara, M., \& Fearnow, S. (1999). Testing the output hypothesis: Effects of output on noticing and second language acquisition. Studies in Second Language Acquisition, 21, 421-452.

Jackson, D., \& Suethanapornkul, S. (2013). The cognition hypothesis: A synthesis and meta-analysis of research on second language task complexity. Language Learning, 63(2), 330-367.

Kim, J. (2012). Task complexity, learning opportunities and Korean EFL learners' question development. Studies in Second Language Acquisition, 34, 627-658.

Koch, P., \& Oesterreicher, W. (1994). Schriftlichkeit und Sprache. In H. Günther \& O. Ludwig (Eds.), Shrift und Shriftlichkeit. Ein interdisziplinäres Handbuch internationaler Forschung [Writing and its use. An interdisciplinary handbook of international research] (pp. 587-604). New York, NY: Mouton de Gruyter.

Kormos, J. (2014). Differences across modalities of performance: An investigation of linguistic and discourse complexity in narrative tasks. In H. Byrnes \& R. M. Manchón (Eds.), Task-based language learning-Insights from and for L2 writing (pp. 193-217). Amsterdam, The Netherlands: John Benjamins.

Kuiken, F., \& Vedder, I. (2011). Task performance in L2 writing and speaking: The effect of mode. In P. Robinson (Ed.), Second language task complexity: Researching the cognition hypothesis of language learning and performance (pp. 91-104). Amsterdam, The Netherlands: John Benjamins.

Kuiken, F., \& Vedder, I. (2012). Speaking and writing tasks and their effects on second language performance. In S. Gass \& A. Mackey (Eds.), The Routledge handbook of second language acquisition (pp. 364-379). New York, NY: Routledge.

Lee, S. K., \& Huang, H. T. (2008). Visual input enhancement and grammar learning: A meta- analytic review. Studies in Second Language Acquisition, 30(3), 307-331.

Leow, R. (1995). Modality and intake in second language acquisition. Studies in Second Language Acquisition, 17(1), 79-89.

Leow, R. (2000). A study of the role of awareness in foreign language behavior. Studies in Second Language Acquisition, 22, 557-584.

Leow, R. P. (2015). Explicit learning in the L2 classroom: A student-centered approach. New York, NY: Routledge.

Levelt, W. J. M. (1989). Speaking: From intention to articulation. Cambridge, MA. MIT Press.

Long, M. H. (1985). A role for instruction in second language acquisition: Task-based language teaching. In K. Hyltenstam \& M. Pienemann (Eds.), Modeling and assessing second language acquisition (pp. 77-99). Clevedon, UK: Multilingual Matters.

Long, M. (2015). Second language acquisition and task-based language teaching. Oxford, UK: Wiley.

Long, M., \& Robinson, P. (1998). Focus on form: Theory, research, and practice. In C. Doughty \& J. Williams (Eds.), Focus on form in classroom second language acquisition (pp. 16-41). Cambridge, UK: Cambridge University Press.

Mackey, A. (Ed.). (2007). Conversational interaction in second language acquisition. Oxford, UK: Oxford University Press.

Mackey, A., \& Goo, J. (2007). Interaction research in SLA: A meta-analysis and research synthesis. In A. Mackey (Ed.), Conversational interaction in second language acquisition: A series of empirical studies (pp. 407-452). Oxford, UK: Oxford University Press.

Manchón, R. (2011). Writing to learn the language: Issues in theory and research. In R. Manchón (Ed.), Learning-to-write and writing-to-learn in an additional language (pp. 61-85). Amsterdam, The Netherlands: John Benjamins.

Manchón, R. M. (2014a). The distinctive nature of task repetition in writing. Implications for theory, research, and pedagogy. ELIA, 14, 13-41.

Manchón, R. M. (2014b). The internal dimension of tasks: The interaction between task factors and learner factors in bringing about learning through writing. In H. Byrnes \& R. M. Manchón (Eds.), Task-based language learning-Insights from and for L2 writing (pp. 27-53). Amsterdam, The Netherlands: John Benjamins. 
Manchón, R. M., \& Roca de Larios, J. (2011). Writing to learn in FL context: Exploring learners' perceptions of the language learning potential of L2 writing. In R. M. Manchón (Ed.), Learning-towrite and writing-to-learn in an additional language (pp. 181-209). Amsterdam, The Netherlands: John Benjamins.

Manchón, R. M., \& Williams, J. (in press). L2 writing and SLA studies. In R. M. Manchón \& P. K. Matsuda (Eds.), The handbook of second and foreign language writing. Boston, MA: De Gruyter Mouton.

Michel, M., Gilabert, R., \& Révész, A., forthcoming Eye-tracking and stimulated recall as means of investigating cognitive load and processes during L2 task performance.

Michel, M., \& Smith, B., (forthcoming). Eye-tracking research in computer-mediated language learning. In S. Thorne \& S. May (Eds.), Encyclopedia of language and education: Language, education, and technology: Vol. 9. Stuttgart, Germany: Springer.

Moser, J., Harris, J., \& Carle, J. (2011). Improving teacher talk. ELT Journal, 66(1), 81-88.

Muranoi, H. (2007). Output practice in the L2 classroom. In R. DeKeyser (Ed.), Practice in a second language: Perspectives from applied linguistics and cognitive psychology (pp. 51-84). Cambridge, UK: Cambridge University Press.

Niu, R. (2009). Effects of task-inherent production modes on EFL learners' focus on form. Language Awareness, 18(3), 384-402.

Oh, S. Y. (2011). Two types of input modification and EFL reading comprehension: Simplification versus elaboration. TESOL Quarterly, 35(1), 69-96.

Olson, D. R., Torrance, N., \& Hildyard, A. (1985). Literacy, language and learning: The nature and consequences of reading and writing. Cambridge, UK: Cambridge University Press.

Park, J. (2011). Learner-generated noticing of written L2 input: What do learners notice and why? Language Learning, 61(6), 146-186.

Philp, J., \& Iwashita, N. (2013). Talking, tuning in and noticing: Exploring the benefits of output in task-based peer interaction. Language Awareness, 22(4), 353-370.

Polio, C. (2012). The relevance of second language acquisition theory to the written error correction debate. Journal of Second Language Writing, 21(4), 375-389.

Ravid, D., \& Tolchinsky, M. (2002). Developing linguistic literacy: A comprehensive model. Journal of Child Language, 29, 419-448.

Rebuschat, P. (2015). Implicit and explicit learning of languages. Amsterdam, The Netherlands: John Benjamins.

Reinders, H. (2005). The effects of different task types on L2 learners' intake and acquisition of two grammatical structures (Unpublished doctoral dissertation). Retrieved from https://researchspace.auckland.ac.nz/bitstream/handle/2292/25/02whole.pdf? sequence $=1$

Reinders, H. (2012). Towards a definition of intake in second language acquisition. Applied Research on English Language, 1(2), 15-36.

Révész, A. (2009). Task complexity, focus on form, and second language development. Studies in Second Language Acquisition, 31, 437-470.

Révész, A., Michel, M., \& Gilabert, R. (2015). Measuring cognitive task demands using dual-task methodology, subjective self-rating, and expert judgments. Studies in Second Language Acquisition. Advance online publication. Retrieved from http://journals.cambridge.org/action/displayAbstract?fromPage=online \&aid= 9951624\&fulltextType=RA\&fileId=S0272263115000339

Robinson, P. (1995). Task complexity and second language narrative discourse. Language Learning, 45, 99-140.

Robinson, P. (2001). Task complexity, cognitive resources, and syllabus design: A triadic framework for examining task influences on SLA. In P. Robinson (Ed.). Cognition and Second Language Instruction (pp. 287-318). Cambridge, UK: Cambridge University Press.

Robinson, P. (2003). The cognition hypothesis, task design and adult task-based language learning. Second Language Studies, 21(2), 45-107.

Robinson, P. (2007). Task complexity, theory of mind, and intentional reasoning: Effects on L2 speech production, interaction, uptake and perceptions of task difficulty. International Review of Applied Linguistics, 45, 193-214.

Robinson, P. (2010). Situating and distributing cognition across task demands: The SSARC model of pedagogic task sequencing. In M. Putz \& L. Sicola (Eds.), Cognitive processing in second language acquisition: Inside the learner's mind (pp. 243-268). Amsterdam, The Netherlands: John Benjamins.

Robinson, P. (2011). Task-based language learning: A review of issues. Language Learning, 61(1), $1-36$. 
Robinson, P., \& Gilabert, R. (Eds.). (2007). Task complexity, the cognition hypothesis and second language instruction [Special issue]. International Review of Applied Linguistics, 45(3), 161-176.

Ruiz-Funes, M. (2015). Exploring the potential of second/foreign language writing for language learning: The effects of task factors and learner variables. Journal of Second Language Writing, 28, $1-19$.

Sachs, R., \& Polio, C. (2007). Learners' uses of two types of written feedback on a L2 writing revision task. Studies in Second Language Acquisition, 29, 67-100.

Samuda, V., \& Bygate, M. (2008). Tasks in second language learning. New York, NY: Palgrave Macmillan.

Sasayama, S., Malicka, A., \& Norris, J. (forthcoming). Cognitive task complexity: A research synthesis and meta-analysis. Amsterdam, The Netherlands: John Benjamins.

Sauro, S. (2011). SCMC for SLA: A research synthesis. CALICO Journal, 28, 369-391.

Schmidt, R. (2001). Attention. In P. Robinson (Ed.), Cognition and second language instruction (pp. 3-32). Cambridge, UK: Cambridge University Press.

Schoonen, R., Snellings, P., Stevenson, M., \& van Gelderen, A. (2009). Towards a blueprint of the foreign language writer: The linguistic and cognitive demands of foreign language writing. In R. M. Manchón (Ed.), Writing in foreign language contexts: Learning, teaching and research (pp. 77-101). Bristol, UK: Multilingual Matters.

Sharwood-Smith, M. (1986). Comprehension versus acquisition: Two ways of processing input. Applied Linguistics, 7, 239-256.

Sharwood-Smith, M. (1993). Input enhancement in instructed SLA. Studies in Second Language Acquisition, 15, 165-79.

Sheen, Y. (2007). The effect of focused written corrective feedback and language aptitude on ESL learners' acquisition of articles. TESOL Quarterly, 41, 255-283.

Skehan, P. (1998). A cognitive approach to language learning. Oxford, UK: Oxford University Press.

Skehan, P. (2009). Modelling second language performance: Integrating complexity, accuracy, fluency and lexis. Applied Linguistics, 30, 510-532.

Smith, B. (2003). The use of communication strategies in computer-mediated communication. System, 31, 29-53.

Swain, M. (1995). Three functions of output in second language learning. In G. Cook \& B. Seidhofer (Eds.), For H. G. Widdowson: Principles and practice in the study of language. A Festschrift on the occasion of his 60th birthday (pp. 125-144). Oxford, UK: Oxford University Press.

Swain, M. (1998). Focus on form through conscious reflection. In C. Doughty \& J. Williams (Eds.), Focus on form in classroom second language acquisition (pp. 64-82). Cambridge, UK: Cambridge University Press.

Swain, M. (2005). The output hypothesis: Theory and research. In E. Hinkel (Ed.), Handbook of research in second language teaching and learning (pp. 471-83). Mahwah, NJ: Erlbaum.

Tavakoli, P. (2014). Storyline complexity and syntactic complexity in writing and speaking tasks. In H. Byrnes \& R. M. Manchón (Eds.), Task-based language learning_Insights from and for L2 writing (pp. 217-236). Amsterdam, The Netherlands: John Benjamins.

Thomas, M., \& Reinders, H. (Eds.). (2010). Task-based language learning and teaching with technology. London, UK: Continuum.

Uggen, M. S. (2012). Reinvestigating the noticing function of output. Language learning, 62(2), 506540 .

VanPatten, B. (2011). Input processing. In S. Gass \& A. Mackey (Eds.), Handbook of second language acquisition. New York, NY: Routledge.

VanPatten, B., Williams, J., \& Rott, S. (2004). Form-meaning connections in second language acquisition. Mahwah, NJ: Erlbaum.

Weissberg, R. (2000). Developing relationships in the acquisition of English syntax: Writing versus speech. Learning and Instruction, 10, 37-53.

Williams, J. (2012). The potential role(s) of writing in second language development. Journal of Second Language Writing, 21, 321-331.

Willis, J. (1996). A handbook for task-based learning. London, UK: Longman.

White, J. (1998). Getting learners' attention: A typographical input enhancement study. In C. Doughty \& J. Williams (Eds.), Focus-on-form in classroom second language acquisition (pp. 85-113). Cambridge, UK: Cambridge University Press. 